\title{
10
}

\section{Indigenous Psychology in Aotearoa/New Zealand and Australia}

\author{
Waikaremoana Waitoki, Pat Dudgeon \\ and Linda Waimarie Nikora
}

The discipline of psychology in Australia [and Aotearoa/New Zealand] has a history of domination over Indigenous Australians [and the people of Aotearoa/New Zealand] that is still evident today. Psychology colonises both directly through the imposition of universalising, individualistic constructions of human behaviour and indirectly through the negation of Aboriginal knowledges and practices. (Dudgeon and Walker 2015, p. 276)

When we find ourselves trapped in the embrace of a western psychology that smothers our self-determination, we need to find ways of letting in the light, fresh air, and new horizons .... (Waitoki 2016, p. 295)

W. Waitoki $(\bowtie) \cdot$ L. W. Nikora

University of Waikato, Hamilton, New Zealand

P. Dudgeon

University of Western Australia, Crawley, WA, Australia

C) The Author(s) 2018 


\section{Introduction}

Globally, Indigenous psychology has emerged as a vibrant, cutting-edge discipline representing a vast range of peoples who have survived colonisation and retained their own therapeutic knowledge systems. Fundamental elements of the term 'Indigenous' includes: selfidentification as indigenous peoples at the individual level, acceptance by the community as a member, historical continuity with pre-colonial and/or pre-settler societies; strong links to territories and surrounding natural resources; distinct social, economic or political systems, distinct language, culture and beliefs; and a determination to maintain and reproduce ancestral environments and systems as distinctive peoples and communities (Cobo 1986).

Indigenous psychology can be understood as a form of cultural reclamation and cultural survival. The practice, theory and science of Indigenous psychology unsettle colonisation while re-centring Indigenous knowledge, or epistemology. Although the discipline of Indigenous psychology is relatively recent, the therapeutic Indigenous knowledge base has been refined over the centuries preceding colonisation (Levy 2016). Definitions of psychology including the study of nature, the human mind and human behaviour, existed well before the colonisation of Aotearoa/New Zealand, and undoubtedly existed in other cultures throughout the world. Such complex knowledge systems were vital to the flourishing of communities and practitioners were respected healers and the guardians of culture.

By supporting and developing culturally appropriate healing, Indigenous psychology is engaged in restoring therapeutic practices and knowledges which have been marginalised and suppressed through centuries of colonisation. Foley (2006) argued that the fencing-in of Indigenous knowledge and Indigenous minds happened at the same time that land and resources were taken, 'the result was the entrapment of our psychic and our thought processes in a cruel educational vacuum that we now call civilization' (p. 26). An Australian and Aotearoa/ New Zealand Indigenous psychology can be argued to share Franz Fanon's commitment to liberating the colonised mind from 'the arsenal 
of complexes that has been developed in the colonial environment' (Fanon 1986, p. 30). The freedom that comes with intellectual emancipation allows deep exploration of Indigenous therapeutic systems that enable cultural connections and transformation.

This chapter relates to the reclamation of Indigenous psychology in Aotearoa/New Zealand and Australia, in particular, the revitalisation of traditional therapeutic knowledge, the de-colonisation of Western psychology, and the focus on self-determination for enhancing the wellbeing of Indigenous peoples. The need for Indigenous psychology is clear: the impact of colonisation the world over is evident in the significant disparities in the way Indigenous peoples, compared to dominant nationalities, access economic, social, political, educational, geographical and psychological capital (Anderson et al. 2016). The ongoing effects of inequities and the structural violence that maintain them are widespread, resulting in significant challenges to Indigenous peoples attempts to preserve their cultural heritage and Indigenous knowledge systems.

\section{Indigenous Psychological Paradigms}

Australian Indigenous psychology explicitly promotes a holistic form of well-being which recognises that self-determination and autonomy, at every level of life, influences the social determinants of health. Aotearoa/ New Zealand offers a Māori way (kaupapa Māori) of Indigenous psychology that includes principles of interrelationships, traditional knowledge, language, autonomy and self-determination.

\section{Social and Political Determinants of Well-Being and Historical Trauma}

The social determinants of health have, at their core, the reality that groups of people are affected by sociopolitical and economic influences such as low education, lack of a living-wage, affordable and safe 
housing, nutritious food, health services; equitable participation in society and political representation (Marmot 2013; WHO 2012). Social and political inequality between Indigenous and non-Indigenous populations in Aotearoa/New Zealand and Australia are apparent in the significant gap between the two groups. For example, the Overview of the Australian Indigenous Health Status 2013, Australian Indigenous HealthInfoNet (2014) found that between '2012-2013, 69\% of Indigenous adults experienced at least one significant stressor in the previous 12 months' (p. 22). Recognised stressors are early family deaths caused by health-related problems; early and repeated incarceration, breakdowns and illness, serious accidents, lack of employment and insecure housing. A prevailing feature of these determinants for Indigenous peoples is the lack of recognition of the effects of structural violence and colonisation and the ongoing depletion of Indigenous peoples resources-see also, \#DAPL Dakota Access Pipeline and \#handsoffourtamariki (hands off our children) in response to forced removal of children (Bedoe 2016).

In Aotearoa/New Zealand, mainstream psychology has been slow to recognise, or research, the impact of historical trauma despite being alerted that Māori were dealing with the consequences of a holocaust within our own country (Turia 2000). The 'historical continuity with pre-invasion and post-colonial societies' (UN 2007: 4) contributes significantly to the legacies of risk and ongoing inequities experienced by Indigenous individuals, families, and communities. The notion of 'historical trauma' was developed in North America to explain Indigenous mental health problems as a result of post-colonial stress, to destigmatise Indigenous peoples, and to reclaim Indigenous therapeutic cultural practice (Baskin 2016; Cajete 2008). Indigenous researchers have steadily increased our understanding of historical trauma and the pivotal role of Indigenous therapeutic interventions (Pihama et al. 2014).

While a relatively recent term in Australian psychological literature, Indigenous Australians also experience historical trauma. It is well known that the collective mental health of Indigenous Australians has been impacted through the often violently oppressive process of colonisation. To refer to a landmark document, the 1997 inquiry into the 
forced separation of children from their families, Bringing Them Home: Report of the National Inquiry into the Separation of Aboriginal and Torres Strait Children from their Families (Wilkie 1997) provided evidence that Indigenous people in Australia have been subjected to genocide as defined by international law (p. 231). The Sydney Aboriginal Mental Health Unit commented that the forced removal of children and the psychological consequences, across several generations, resulted in incalculable trauma, depression and major mental health problems for Aboriginal people.

...initially the systematic forced removal of children and now the continuing removal by Community Services or the magistracy for detention of children has been tantamount to a continuing cultural and spiritual genocide both as an individual and a community experience and we believe that it has been the single most significant factor in emotional and mental health problems which in turn have impacted on physical health. (Wilkie 1997, p. 171)

Despite the numerous barriers Indigenous peoples face, they thrive and resist, signaling a renaissance of visible Indigenous culture within Aotearoa/New Zealand and Australia. One of the more significant gains made has been the rapid growth of an Indigenous mental health movement which is actively reforming policy, contributing to public awareness of the social determinants of Indigenous well-being, and restoring the authority of cultural healers. Recognition of the impact of historical trauma is necessary across psychology if Indigenous worldviews are to find a firm foothold in the profession.

In 2016, the Australian Psychological Society offered a formal apology to Indigenous people for the ways in which the discipline, psychologists, researchers and academics, had actively discriminated against the traditional custodians of the land. The apology ended with the expectation of a future 'where Aboriginal and Torres Strait Islander people enjoy the same social and emotional well-being as other Australians' (NACCHO 2016). Aotearoa/New Zealand psychology professions have yet to recognise their complicit role in contributing to abuses perpetrated by psychological theories and practices. 


\section{Kaupapa Māori Psychology: An Indigenous Psychology}

While the Treaty of Waitangi is an important local instrument in our New Zealand context, internationally, the United Nation's Declaration on the Rights of Indigenous Peoples (UNDRIP) (Cobo 1986) provides pathways for Indigenous peoples to self-determination and self-governance with health contexts. Indigenous psychology in $\mathrm{New}$ Zealand is closely aligned with the Māori development agenda, the goal of which 'is to create psychologies to meet the needs of Māori people in a way that maintains a unique cultural heritage, and makes for a better collective Māori future' (Nikora et al. 2006, pp. 254-255).

An important feature of Indigenous psychology in Aotearoa/New Zealand stems from the understanding that Māori resist their exclusion, as Māori, from participating in therapeutic spaces. The term kaupapa Mãori, refers to the philosophy and practice of being and acting Mãori (Smith 1999) where Māori values, and worldviews about relationships are central. Kaupapa Māori theory is the operationalisation of selfdetermination-tino rangatiratanga and through its alignment with critical theory, has elements of conscientisation, resistance and praxis (Pihama 2001; Smith 1999). Māori epistemologies provides a lens to view the relational phenomena of the world, taking into account Māori methods of comprehending, observing and experiencing those things that exist, has existed, and may yet exist (Waitangi Tribunal 2011). A Māori scientific lens applied to exploring phenomenon is problematic in Western contexts as positivism and reductionism prevail.

An Indigenous psychology in Aotearoa/New Zealand has firm foundations in mātauranga Māori-Māori knowledge (Levy and Waitoki 2016). Reclaiming that knowledge allows us to theorise a pathway in psychology that meets our Indigenous needs. Māori understandings of well-being are similar to Indigenous Australians where relationships and healthy connection to others, either family, friends, or communities, is central. Whānau Ora, 'healthy families', is a Māori-led initiative where Māori families are supported to achieve, and assess, their maximum health and well-being (Office of the Auditor General 2015). 
The Whànau Ora philosophy recognises that families are a collective entity, with the capacity for self-determination; that family is built on a Māori cultural foundation, and that families can have a positive role within society (Boulton and Gifford 2014).

Understanding the relational nature of health and well-being is pivotal, as is understandings of Māori cultural knowledge and practice. Research conducted by Māori psychologists, show that Māori knowledge is being incorporated into every facet of psychology: clinical, community, education, neuropsychology, teaching and research (Waitoki 2016; Love and Waitoki 2007). Despite the lack of sufficient course content in University psychology training programmes, Māori consumers are being treated with either culturally-adapted Western psychological therapies, or Indigenous Māori practices (Waitoki 2016). Although both forms of practice use distinctly Māori processes, in the culturally-adapted approach, Western psychology is part of the assessment and treatment modality. Indigenous knowledge and practice include: Manaakitanga-hospitality, sharing food, sharing resources and showing genuine care and support; Using karakia-ceremony/prayer/ protocols to create a culturally safe space that settles clients, opens connections, affirms cultural worldviews, and embraces the client's language and values; Whakawhanaungatanga-building relationships relating to open disclosures about genealogical and cultural links that may exist between clients and therapists. Such disclosures enable a shift in power, and confirms the importance of relationships between people, and the importance of connections via land and sea, history, and language, time and space. The salience of building relationships is embedded in Māori identity as Māori, and is based on tribal affiliations and family links, which are not typically seen in Western psychology (Valentine 2016).

Indigenous practices used to engage with clients include extensive engagement processes such as: mihimihi (ceremonial greetings); tikanga (ethics and moral codes); self-disclosure of genealogical links-whakapapa; and karakia-invocations, Māori arts and technologies, and physical and environmental connections. Indigenous psychology for Māori, incorporates the use of social connections, Māori language, and personal contact, sharing intimate stories, and using strategies to enhance cultural identity and raise potentiality (Macfarlane and Macfarlane 2012; 
Pitama et al. 2014). These practices underpin Māori cultural practices essentially establishing a relationship that is based on shared knowledge about each person in the therapeutic relationship, thereby countering the notion of the psychologist as the sole holder of knowledge. Furthermore, the deep connections established in the engagement process establishes a reciprocal relationship that is based on possible genealogical, geographical and community interests.

Māori relational worldviews have played a vital role in reshaping therapeutic interventions while maintaining the cultural dignity of those involved in situations where risk and vulnerabilities exist, such as drug and alcohol abuse, sexual violence and suicidality (Emery et al. 2015; Lawson-Te Aho 2016). Although personal disclosure is seen as ethically unsafe within Western psychology, Māori people build trust and respect through open disclosure about family, geographical links, schooling, and other personal connections. Issues of safety are also important and Māori therapists ensure that their disclosure is bound within the cultural worldviews of Māori engagement processes, so that deep personal details that may be used inappropriately are avoided.

Blending traditional and contemporary knowledge of Māori creation stories (Kopua and Rangihuna 2015) and new technologies in psychology is an important feature of Indigenous psychology. Cherrington (2016) offers a Māori-focused intervention based on pürakau/storytelling: '[T] raditionally, pürakau have been handed down from generation to generation to provide advice and insights to the thoughts, actions, and feelings of our ancestors' (p. 118). The principles contained within the pürakau method are wānanga-discussion and debate, power-sharing and talking story (Taitimu 2016). The end-user decides which method they use to tell their story which typically includes the use waiata — songs, body adornment, or traditional tattoo; and haka-creative performance; poetry, drama, weaving, sculpting, painting, drawing, storytelling, and/or writing.

The role of Māori processes in therapeutic interventions is to facilitate a secure cultural identity, to develop balanced relationships, and to enhance well-being. The reclamation of Indigenous practices means that the knowledge derived from ancestral origins and handed down through the centuries are drawn on to reframe psychology. Smith et al. (2016) comment on the importance of recognising the expertise in our 
communities, particularly the knowledge holders who possess a level of skill that is not valued, or understood by mainstream spaces.

... those extraordinary, metaphysical tasks, such as mediating the material and spiritual world, escorting a spirit on a physical and spiritual journey, binding ancient genealogies with contemporary realities, sustaining relationships while healing collective grief, seeking visions and teachings from our ancestors, or cleansing people and spaces. (p. 132)

The knowledge systems embedded in the above statement point to a reality in Western psychological spaces: Indigenous peoples who speak of deceased ancestors, esoteric beliefs or spiritual events are pathologised and labelled as deficit and psychotic. Indigenous psychologists understand the role of metaphysics and can artfully blend bicultural knowledge systems to avoid exposing consumers to continued colonisation in systems that overlook the importance of such systems (Wirihana and Smith 2014).

An emerging Indigenous health framework for Māori based on the Meihana model (Pitama et al. 2014) and 'te whare tapa wha' (the foursided house) developed by Mason Durie (1994) is gaining traction with health settings. The refined model, 'Te waikare o te waka o Meihana'the rippling waters from the Meihana canoe, is an Indigenous health framework comprising elements of engagement ( $h u$ i) formal greetings, establishing connections, attending to the purpose of the encounter, and closing protocols. The connections made via a therapeutic context extend beyond formalised, Western processes of non-disclosure, and detachment. The second part of the Indigenous health framework shows a metaphoric representation of consumers as a double-hulled, ocean vessel with six crossbeams representing elements integral to Māori wellbeing: physical (tinana), psychological (hinengaro), service connections (iwi katoa), spirituality (wairua) and environment (taiao).

The double hull of the ocean vessel represents the client on one side and family on the other. The contextual factors that influence consumer well-being such as colonisation, racism, migration, and marginalisation are represented by the four winds. The metaphors of ocean currents enable practitioners to consider personal connections to Māori culture, adherence to Māori cultural principles, interpersonal relationships, and 
connections to land. Navigation relates to setting an appropriate course for clients that takes into account all the features described within a Māori worldview and taking into account relevant clinical features. The goal of the model is for health practitioners to consider, clinically and culturally, the multiple influences that impact decisions made about, and for Māori clients. The Meihana model was recently redeveloped for clinical psychology and called the 'Hauora model' (the wellbeing model, Pitama et al. 2017). The model has synergies with Australian health models indicating the common features of Indigenous experiences and well-being goals.

\section{Australian Context and Emerging Therapeutic Knowledges}

For Indigenous people, cultural identity is the foundation of who we are. Despite years of assimilationist policy, and the loss of so many of our customs and languages, Aboriginal people have demonstrated extraordinary cultural resilience. (Dudgeon 2014, p. 6)

Indigenous Australia is made up of two distinct cultural groups, the majority, mainland Aboriginal people and a minority, Torres Strait Islander people. This chapter uses the term Indigenous to refer to both groups. Indigenous Australians belong to the oldest living culture in the world, and indeed the oldest sustainable, equitable and harmonious culture in the world. According to estimates by archaeologists, the Indigenous Australian culture is between 60,000 and 70,000 years old (Australian Science Media Centre 2016). The colonisation of Australia in 1788 has had a lasting impact on the social and emotional well-being of Indigenous peoples. Forced displacement from land, massacres, introduced diseases, sexual violence, enslavement, and the systemic destruction of cultural life have resulted in complex forms of trauma and socioeconomic deprivation (Dudgeon et al. 2014). In the late eighteenth century some two hundred and fifty languages and six hundred dialects were recorded but by the early twenty-first century only approximately one hundred and fifty language groups remained, with approximately 20 in everyday use and 13 near extinction (Obata and Lee 2010). This attrition is a clear indication of the destructive impact of colonisation. 
Indigenous Australians and Māori, have survived several waves of institutionalised racism (Dudgeon et al. 2016b). The Protectionists era began in the late 1800s: The colonising government, under instruction from the British Empire, sought to preserve from extinction a people viewed as primitive and without culture. The Aboriginal Act of 1905 in Western Australia, for example, placed all Indigenous people under surveillance and state control, restricting movement, employment, and the right to partner (Dudgeon 2008). The Assimilationist era, which overlapped, is often recognised as officially starting with a decision made at a national 1937 Commonwealth Government conference where it was agreed that Indigenous children, who were not 'full blood,' would be removed from their families and placed in orphanages and white foster homes (Dudgeon et al. 2015).

Resistance against colonial dispossession is ongoing. Among many landmark achievements is the 1966 Northern Territory Wave Hill strike by the Gurindji people which mobilised the Indigenous land rights movement, a movement which is central to self-determination. The 1967 referendum granted the semblance of self-determination by being counted as citizens in the consensus. During what some political historians describe as the self-determination era, the Aboriginal and Torres Strait Islander Commission (ATSIC) was established as the first national self-governing Indigenous body in 1990 (although abolished by a Conservative government in 2005). The Australian High Court 'Mabo' decision of June 1992 recognised the rights of the Meriam people of Murray Island (Mer) over their own land-the colonial fiction of 'terra nullius' was replaced by Indigenous self-determination. The Native Title Act of 1993, and the 1996 'Wik' Indigenous land rights decision, also strengthened self-determination.

\section{Social and Emotional Well-Being and Indigenous Therapeutic Knowledges}

Social and emotional well-being is an emerging paradigm within Australian Indigenous psychology, informing a range of policy interventions, research, and therapeutic practices. This emerging paradigm has 
both de-colonised dominant white mental health policy and practice (Dudgeon and Walker 2015), and re-centred Indigenous therapeutic epistemologies as the foundation of praxis and theory. The Australian Indigenous mental health movement has promoted a recognition of social and emotional well-being through key mental health policies (Fig. 10.1).

The concept of Indigenous social and emotional well-being was first developed in 1989 by the National Aboriginal and Islander Health Organisation (NAIHO) which defined Aboriginal health as:

The social, emotional and cultural well-being of the whole Community in which each individual is able to achieve their full potential as a human being, thereby bringing about the total well-being of their Community. It is a whole-of-life view and includes the cyclical concept of life-death-life. (National Aboriginal Health Strategy Working Party 1989)

This concept of health was taken up in the 1989 National Aboriginal Health Strategy which identified nine principles for Aboriginal and Torres Strait Islander social and emotional well-being, which have since guided practice and policy in the area. For example, these principles are contained in the National Strategic Framework for Aboriginal and Torres Strait Islander Peoples Mental Health and Social and Emotional Well-being 2004-2009. The Framework defined Indigenous social and emotional well-being as a holistic connection to the domains of 'land, culture, spirituality, ancestry, family and community' (SHRG 2004, p. 9).

Protocols for the delivery of social and emotional well-being and mental health services in Indigenous communities were released in 2009 (Haswell et al. 2009). Since then the psychology of Indigenous social and emotional well-being has evolved into a composite of seven inter-connected domains: country, mind and emotions, body, family and kinship, community, culture, and spirituality (Dudgeon and Walker 2015). Together these domains can be said to describe Indigenous selfhood. Flourishing connections between these domains can be understood as the dynamics of Indigenous thriving. The result of a lack of balanced connection between the seven domains is impaired health which 'may be manifested in a physical, social, emotional, mental or 


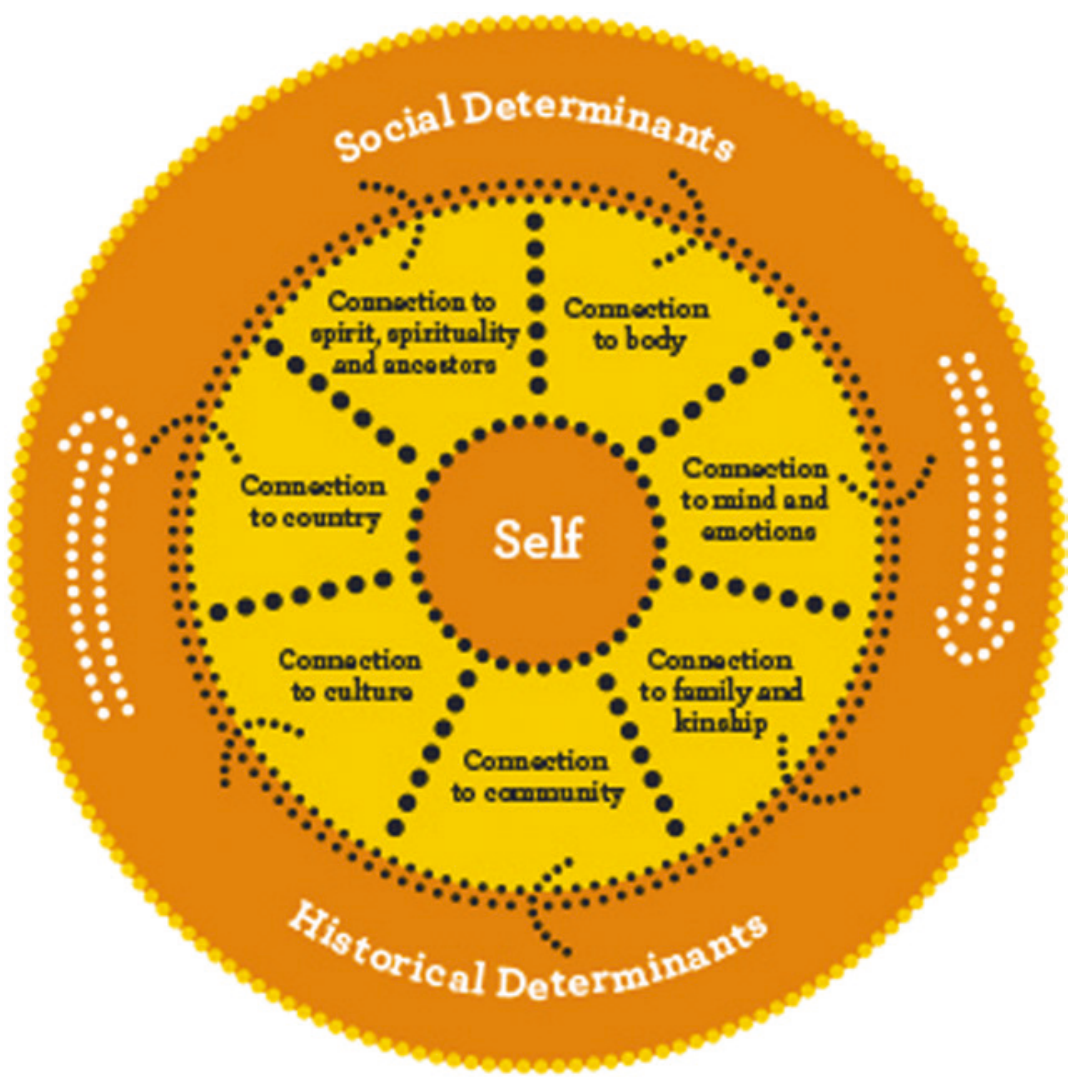

Fig. 10.1 Social and emotional well-being diagram (Source Dudgeon and Walker 2015)

spiritual manner' (Haswell et al. 2009, p. 3). Intergenerational trauma caused by the forced removal of children has been identified as a significant disruption to Indigenous social and emotional well-being (SHRG 2004, p. 9).

Central to Indigenous social and emotional well-being psychology is the recognition that well-being has been compromised through colonisation, and that self-determining therapeutic practices are most effective in healing historical trauma, and other consequences of colonisation. Here it is acknowledged that social and emotional well-being although an emerging paradigm, is rooted in the cultural history of Indigenous life: 
Aboriginal social life has provided a framework for social, psychological and economic security, in which well-being was socially determined through the organisation of relationships with the land and with people within frameworks of law and ceremony, family organisation and systems of belief known as 'The Dreaming'. (CRCAH 2009, p. 3)

Spirituality is recognised as a bedrock of Indigenous mental health (Riley 1997). 'Aboriginal well-being relies on a belief system, that philosophical basis of ontologies and epistemologies known as Spirituality' (Grieves 2009, p. 42). The focus on Dreaming and spirituality significantly enhances our understanding of how Indigenous knowledge has informed our psychology. A common term for Aboriginal philosophical ontologies and epistemologies is The Dreaming which is sometimes called the Law or the Lore. The Dreaming holds life in place and together.

Indigenous words for the complex spiritual (and sociopolitical) system are numerous, for example, the Aranada use the term Altjiringa, the Altjidja people refer to the Djugar, the Karadjeri people call this past, present and future Lore; the Bugari, the Ungarinyin describe the Unggud, and the Wiradjeri call the synthesis between human and non-human, seen and unseen, the Maratal (Elkin 1969). The philosophy of the Dreaming encompasses a connection to the morethan-human, the intermingling of the past, present and future, and to the seen, and unseen (Grieves 2009, p. 17). This philosophy is referred to as the Law because it is the foundation of 'morality, ethics, governance, natural resource management, and social and familial relationships that are designed to ensure sustainability and effective governance and sociality' (Grieves 2009, p. 12). Moreover, the purpose of this Law is to guard and nurture life: 'Mission: keep all alive' (Sveiby and Scuthorpe 2006, cited in Grieves 2009, p. 15, emphasis added).

During the last few decades once suppressed therapeutic practices have re-emerged across the nation, and various Indigenous mental health policies now acknowledge their importance in closing the mental health gap between Indigenous and non-Indigenous peoples. For example, the landmark Australian 2015 Gayaa Dhuwi (Proud Spirit) Declaration requests that traditional healing become a central part of 
culturally appropriate practices: 'building access to cultural healers and cultural healing' is the primary task for implementing the Declaration (Dudgeon et al. 2016a, p. 7). Gayaa Dhuwi emerged from the 2010 Wharerata Declaration created by mental health leaders from Canada, Australia, New Zealand, Samoa and the United States with the support of the International Initiative for Mental Health Leadership. There are five central themes in the Wharerata Declaration: Indigeneity; best practice; best evidence; informed, credible, strategic, connected sustainable leadership; influential and networked leadership (Sones et al. 2010).

The 2014, West Australian Mental Health Act also acknowledges the right of Indigenous people to have access to cultural or traditional healers: Principle 7 states that Aboriginal and Torres Strait Islander people must be provided with access to traditional healers and also to Elders in their community during the process of assessment, treatment, and care (Dudgeon 2014). This is also part of a cultural renaissance in which the engagement of Elders in Indigenous mental health is now recognised as vital to the healing benefits of cultural continuity and the survival of cultural practices. The 2014 release of the results of a nation-wide consultation with Elders about the epidemic of youth suicides People Culture Environment and One Generation Media (2014), advised repeatedly that the role of Elders in reconnecting youth to cultural practices is important in overcoming the alienation, social isolation and cultural disconnection which are a pathogenic outcome of colonisation.

Traditional healing practices are complex and varied and are referred to by many language names. For example, the western desert name is Ngangkari, and in Arnhem Land traditional healers are called the Marrnggitj (Elkin 1969). The Ngangkari group of healers have become more visible in the last couple of decades. As Dudgeon and Walker write, the traditional spiritual healers, the Ngangkari, 'have nurtured the physical, emotional, and social well-being of Indigenous people across 350,000 square miles of the remote western desert of Australia for thousands of years' (Dudgeon and Walker 2015, p. 290). Across this vast area, the Ngaanyatjarra Pitjantjatjara Yankunytjatjara (NPY) (2013) Women's Council have practiced spiritual healing, and done much to strengthen a national awareness about traditional therapeutic practices. 


\section{Conclusion}

Indigenous psychology is the search by Indigenous peoples for a voice in their own futures and well-being. The reclamation of Indigenous psychology enables the creation of new, dynamic paradigms within which psychological distress can be addressed. In Aotearoa/New Zealand, Australia, or any other colonised nation, Indigenous peoples are a family, and as such, have a bond based on indigeneity, and survival. Indigenous psychology is in its formative years, and in some places is still marginalised by mainstream health and education systems. However, Indigenous and non-indigenous practitioners, researchers and scholars have moved towards changing the status quo so that it is possible to have Indigenous psychology institutions offering qualifications, assessment and intervention protocols, and to have a robust literature base. The goal of an Indigenous psychology is for Indigenous peoples to see their worldviews reflected back to them when they seek help for themselves, their families or their communities.

\section{References}

Anderson, I., Robson, B., Connolly, M., Al-Yaman, F., Bjertness, E., King, A., et al. (2016). Indigenous and tribal peoples' health (The LancetLowitja Institute Global Collaboration): A population study. The Lancet, 388(10040), 131-157.

Australian Indigenous HealthInfoNet. (2014). Overview of Australian Indigenous health status, 2013. Retrieved from http://www.healthinfonet. ecu.edu.au/health-facts/overviews.

Australian Science Media Centre (Ed.). (2016). Aboriginal gnome reveals new insights into early humans. Australasian Science, Nov/Dec 2017. Retrieved September 5, 2017, from http://www.australasianscience.com.au/article/issuenovember-2011/aboriginal-genome-reveals-new-insights-early-humans.html.

Baskin, C. (2016). Strong helpers' teachings: The value of indigenous in the helping profession. Toronto: Canadian Scholars' Press.

Bedoe, L. (2016). Hands off our tamariki: An open letter. Retrieved September 5, 2017, from http:/www.reimaginingsocialwork.nz/2016/10/ hands-off-our-tamariki-an-open-letter/. 
Boulton, A., \& Gifford, H. (2014). Conceptualising the link between resilience and whanau ora. MAI Journal, 3(13), 112-129.

Cajete, G. (2008). Seven orientations for the development of indigenous science education. In N. Denzin, Y. Lincoln, \& T. Smith (Eds.), Handbook of critical and indigenous methodologies (pp. 487-498). Thousand Oaks: Sage.

Cherrington, L. (2016). Re: "I just want to heal my family". In W. Waitoki \& M. Levy (Eds.), Te manu kai i te mätauranga: Indigenous psychology in Aotearoa/New Zealand (pp. 115-133). Wellington: Roopu Mātai Hinengaro, New Zealand Psychological Society.

Cobo, M. (1986). Study of the problem of discrimination against indigenous populations. UN Doc.E/CN.4/Sub.2/1986/7/Add.4, paras. 379-380.

CRCAH (Cooperative Research Centre for Aboriginal Heath). (2009). Spirituality and Aboriginal people's social and emotional wellbeing: A review. Darwin: CRCAH.

Dudgeon, P. (2008). Mothers of sin: Indigenous women's perceptions of their identity and gender. Unpublished doctoral thesis, Murdoch University, Perth, Australia.

Dudgeon, P. (2014). Introduction. In People Culture Environment and one Generation Media (Ed.), The Elders' report into preventing Indigenous selfharm and youth suicide. Retrieved September 5, from http://www.cultureislife.org/wp-content/uploads/2015/10/Elders-Report.pdf.

Dudgeon, P., Calma, T., Brideson, T., \& Holland, C. (2016a). The Gayaa Dhuwi (proud spirit) declaration-A call to action for Aboriginal and Torres Strait Islander leadership in the Australian mental health system. Advances in Mental Health, 14(2), 1-14.

Dudgeon, P., Cubillo, C., \& Bray, A. (2015). The Stolen Generations: The forced removal of First Peoples children in Australia. In C. Newnes (Ed.), Children in society: Politics, policies and interventions (p. 5081). Ross-onWye: PCCS Books.

Dudgeon, P., Darlaston-Jones, D., Nikora, L. W., Waitoki, W., Pe-Pua, R., Tran, L., et al. (2016b). Changing the acculturation conversation: Indigenous cultural reclamation in Australia and Aotearoa/New Zealand. In D. L. Sam \& J. W. Berry (Eds.), The Cambridge handbook of acculturation psychology (2nd ed., pp. 115-133). Cambridge: Cambridge University Press. https://doi.org/10.1017/cbo9781316219218.009.

Dudgeon, P., Milroy, H., \& Walker, R. (2014). Working together: Aboriginal and Torres Strait Islander mental health and wellbeing principles and practice (2nd ed.). Canberra: Commonwealth of Australia. Retrieved September 5, 2017, from https://www.telethonkids.org.au/globalassets/media/documents/aboriginal-health/working-together-second-edition/working-together-aboriginal-and-wellbeing-2014.pdf. 
Dudgeon, P., \& Walker, R. (2015). Decolonising Australian psychology: Discourses, strategies, and practice. Journal of Social and Political Psychology, 3(1), 276-297. Retrieved December 11, from https://jspp.psychopen.eu/ article/view/126/html.

Durie, M. (1994). Whaiora: Maori health development. Auckland: Oxford University Press.

Elkin, A. P. (1969). Elements of Australian Aboriginal philosophy. Oceania, 40, 85-98.

Emery, T., Cookson-Cox, C., \& Raerino, N. (2015). Te waiata i roto i a Te Arawa: A Māori suicide research project. AlterNative: An International Journal of Indigenous Peoples, 11(3), 226-239.

Fanon, F. (1986). Black skin, white masks (C. L. Markmann, Trans.). London: Pluto Press.

Foley, D. (2006). Indigenous standpoint theory. International Journal of the Humanities, 3(8), 25-36.

Grieves, V. (2009). Aboriginal spirituality: Aboriginal philosophy, the basis of Aboriginal social and emotional wellbeing (Discussion Paper No. 9). Darwin: Cooperative Research Centre for Aboriginal Health. Retrieved November 12, 2017, from https://www.lowitja.org.au/sites/default/files/docs/DP9Aboriginal-Spirituality.pdf.

Haswell, M., Hunter, E., Wargent, R., Hall, B., O’Higgins, C., \& West, R. (2009). Protocols for the delivery of social and emotional wellbeing and mental health services in Indigenous communities: Guidelines for health workers, clinicians, consumers and carers (1st ed.). Cairns: University of Queensland and Queensland Health. Retrieved November 30, from https://www.health.qld. gov.au/_data/assets/pdf_file/0029/378731/acknow_foreward.pdf.

Kopua, M., \& Rangihuna, D. (2015). Mahi a atua: Te ara a Tāne \& moko as healing. Oral presentation. Tairawhiti District Health Board, 27th August, Gisborne.

Lawson-Te Aho, K. (2016). He waka eke noa-Māori and indigenous suicide prevention: Models of practice, lessons and challenges. In W. Waitoki, J. Feather, N. Robertson, \& J. Rucklidge (Eds.), Professional practice of psychology in Aotearoa/New Zealand (3rd ed.). Wellington: New Zealand Psychological Society.

Levy, M. (2016). Kaupapa Māori psychologies. In W. Waitoki \& M. Levy (Ed.), Te manu kai $i$ te mätauranga: Indigenous psychology in Aotearoal New Zealand (pp. 29-41). Wellington: New Zealand Psychological Society, Roopu Mātai Hinengaro. 
Levy, M., \& Waitoki, W. (2016). Our voices, our future: Indigenous psychology in Aotearoa. In W. Waitoki, J. Feather, N. Robertson, \& J. Rucklidge (Eds.), Professional practice of psychology in Aotearoa/New Zealand (3rd ed.). Wellington: New Zealand Psychological Society.

Love, C., \& Waitoki, W. (2007). Multicultural competence in bicultural Aotearoa. In I. Evans, J. Rucklidge, \& M. O’Driscoll (Eds.), Professional practice of psychology in Aotearoa New Zealand (pp. 265-280). Wellington: New Zealand Psychological Society.

Macfarlane, S., \& Macfarlane, A. (2012). Diversity and inclusion in early childhood education: A bicultural approach to engaging Māori potential. In A. Smith \& R. Bishop (Eds.), He Ao Türoa Tãtaki. Inclusive early childhood education: Perspectives on inclusion, social justice and equity from Aotearoa/New Zealand (pp. 21-38). Wellington: New Zealand Council for Educational Research.

Marmot, M. (2013). Health inequalities in the EU-Final report of a consortium. Consortium lead: Sir Michael Marmot. Brussels: European Commission Directorate-General for Health and Consumers. Retrieved November 10, 2017, from https://ec.europa.eu/health//sites/health/files/ social_determinants/docs/healthinequalitiesineu_2013_en.pdf.

NACCHO. (2016). Australian Psychological Society issues a formal apology to Aboriginal and Torres Strait Islander people. Retrieved September 5, 2017, from https://nacchocommunique.com/2016/09/15/naccho-aps2016-australian-psychological-society-issues-a-formal-apology-to-aboriginal-and-torres-strait-islander-people/.

National Aboriginal Health Strategy Working Party. (1989). A National Aboriginal Health Strategy. Canberra: National Aboriginal Health Strategy Working Party.

Ngaanyatjarra Pitjantjatjara Yankunytjatjara Women's Council Aboriginal Corporation. (2013). Aboriginal corporation: Working together, traditional healers of central Australia: Ngangkari. Broome, WA: Magabala Books.

Nikora, L. W, Levy, M., Masters-Awatere, B., \& Waitoki, W. (2006). Global development and characteristics and local development. In C. M. Allwood $\&$ J. W. Berry (Eds.). Origins and development of indigenous psychologies: An international analysis. International Journal of Psychology, 41(4), 243-268 (pp. 254-255). Retrieved November 10, 2017, from http://indigenouspsych.org/Resources/Allwood\%20\&\%20Berry.pdf.

Obata, K., \& Lee, J. (2010). Languages of Aboriginal and Torres Strait Islander peoples-A uniquely Australian heritage. Yearbook Australia, 2009-2010. 
Retrieved November 10, 2017, from http://www.abs.gov.au/AUSSTATS/ abs@.nsf/Lookup/1301.0Feature+Article42009\%E2\%80\%9310.

Office of the Auditor General. (2015). Whannau Ora: The first four years (Report Issued by the Audiotr-General). Wellington, New Zealand. Retrieved November 16, from https:/oag.govt.nz/2015/whanau-ora/docs/ whanau-ora.pdf.

People Culture Environment in Partnership with Our Generation Media (Ed.). (2014). The Elders' report into preventing Indigenous self-harm and youth suicide. Retrieved September 5, from http://www.cultureislife.org/ wp-content/uploads/2015/10/Elders-Report.pdf.

Pihama, L. (2001). Tihei mauri ora: Honouring our voices. Mana wabine as a kaupapa Mãori theoretical framework. Unpublished Ph.D. thesis, University of Auckland, New Zealand.

Pihama, L., Smith, C., Reynolds, P., Smith, L. T., \& Te Nana, R. (2014). Positioning historical trauma theory within Aotearoa New Zealand. AlterNative: An International Journal of Indigenous Peoples, 10(3), 248-262.

Pitama, S., Bennett, S., Waitoki, W., Valentine, H., Haitana, T., Pahina, J. ... McLaughlan, A. (2017). Hauora Māori clinical guide for psychologists: Using the Hui process and the Meihana model in clinical assessment and formulation. New Zealand Journal of Psychology, 46(3).

Pitama, S. G., Huria, T., \& Lacey, C. (2014, May 2). Improving Māori health through clinical assessment: Waikare o te waka o Meihana. New Zealand Medical Journal, 127(1393), Viewpoint Article. Retrieved November 10, 2017, from https://www.nzma.org.nz/journal/read-the-journal/ all-issues/2010-2019/2014/vol-126-no-1393/viewpoint-pitama.

Riley, R. (1997). From exclusion to negotiation: The role of psychology in Aboriginal social justice (Discussion Paper [Curtin Indigenous Research Centre] No. 1/1997). Perth, WA: Gunada Press, Curtin University.

SHRG (Social Health Reference Group). (2004). National strategic framework for Aboriginal and Torres Strait Islander peoples' mental health and social and emotional wellbeing 2004-2009. Canberra: Australian Department of Health and Ageing. Retrieved November 10, from http://www.ahmrc.org. $\mathrm{au} / \mathrm{media} /$ resources/social-emotional-wellbeing/mental-health/328-national-strategic-framework-for-aboriginal-and-torres-strait-islander-peoplesmental-health-and-social-and-emotional-well-being-2004-2009/file.html.

Smith, L. T. (1999). Decolonising methodologies: Research and Indigenous peoples. Dunedin: University of Otago Press. 
Smith, L. T., Maxwell, T. K., Puke, H., \& Temara, P. (2016). Indigenous knowledge, methodology and mayhem: What is the role of methodology in producing indigenous insights? A discussion from mātauranga Māori. Knowledge Cultures, 4(3), 131-156.

Sones, R., Hopkins, C., Manson, S., Watson, R., Durie, M., \& Naquin, V. (2010). The Wharerata Declaration-The development of indigenous leaders in mental health. The International Journal of Leadership in Public Service, 6(1), 53-63.

Taitimu, M. (2016). A new moon. Talking story with Ripeka to support the healing of soul wounds In W. Waitoki \& M. Levy (Eds.). Te manu kai i te matauranga: (Indigenous psychology) in AotearoalNew Zealand (pp. 141153). Wellington: New Zealand Psychological Society.

Turia, T. (2000). Keynote address. New Zealand Psychological Society Conference 2000 at Waikato University, 29 August.

UN (United Nations). (2007). United Nations declaration on the rights of indigenous people. New York: United Nations. Retrieved September 5, 2017, from http://www.un.org/esa/socdev/unpfii/documents/DRIPS_en.pdf.

Valentine, H. (2016). Wairuatanga. In W. Waitoki \& M. Levy (Eds.), Te manu kai i te mātauranga: Indigenous psychology in Aotearoa/New Zealand (pp. 155-169). Wellington, New Zealand: New Zealand Psychological Society, Roopu Mātai Hinengaro.

Waitangi Tribunal. (2011). Ko Aotearoa tènei: A report into claims concerning New Zealand law and policy affecting Māori culture and identity (Wai 262: Waitangi Tribunal Report). Wellington: Waitangi Tribunal. Retrieved November 10, 2017, from https://forms.justice.govt.nz/search/Documents/ WT/wt_DOC_68356054/KoAotearoaTeneiTT1W.pdf.

Waitoki, W. (2016). Ngā kete mātauranga: The baskets of knowledge, a curriculum for an indigenous psychology. In W. Waitoki \& M. Levy (Eds.), Te manu kai i te mätauranga: Indigenous psychology in Aotearoa/New Zealand (pp. 288-299). Wellington: New Zealand Psychological Society, Roopu Mātai Hinengaro.

WHO (World Health Organisation). (2012). Social determinants of health (Report by the Secretariat, EB132/4). Geneva: WHO. Retrieved November 10, 2017, from http://www.who.int/social_determinants/B_132_14-en.pdf. Wilkie, M. (1997). Bringing them home: Report of the national inquiry into the separation of Aboriginal and Torres Strait Islander children from their families. Sydney, NSW: Human Rights and Equal Opportunity Commission. 
Retrieved November 10, 2017, from https:/www.humanrights.gov.au/sites/ default/files/content/pdf/social_justice/bringing_them_home_report.pdf. Wirihana, R., \& Smith, C. (2014). Historical trauma, healing and well-being in Māori communities. MAI Journal, 3(3), 197-210. Retrieved September 5, 2017, from http://www.journal.mai.ac.nz/sites/default/files/MAI_Jrnl_3(3)_ Wirihana02.pdf. 